\title{
THE CO-EVOLUTION OF THE NITROGEN, CARBON AND OXYGEN CYCLES IN THE PROTEROZOIC OCEAN
}

\author{
KATJA FENNEL*, MICK FOLLOWS**, PAUL G. FALKOWSKI*
}

\begin{abstract}
Geochemical evidence suggests that there was a delay of several hundred million years between the evolution of oxygenic photosynthesis and the accumulation of oxygen in Earth's atmosphere. The deep ocean appears to have remained euxenic for several hundred million years after the atmosphere became oxygenated. In this paper we examine the possibility that the extraordinary delay in the oxidation of the atmosphere and oceans was caused by a biogeochemical "bottleneck" imposed by metabolic feedbacks between carbon burial, net oxygen production, and the evolution of the nitrogen cycle in the Proterozoic oceans. Whereas under anoxic conditions oceanic ammonium would have been relatively stable, as oxygen concentrations rose, nitrification and subsequent denitrification would have rapidly removed fixed inorganic nitrogen from the oceans. Denitrification would have imposed a strong constraint on the further rise of free oxygen by depriving oxygenic photoautotrophs of an essential nutrient (that is, fixed inorganic nitrogen). To examine the dynamic interactions between oxygen and nitrogen cycling, we developed a five box model that incorporates the salient features of the oxygen, nitrogen and carbon cycles, ocean circulation, and ocean-atmosphere gas-exchange. Model simulations, initiated under anaerobic conditions with no free oxygen in the atmosphere or ocean, are characterized by an initially reduced deep ocean with abundant ammonium, followed by an extended period when neither form of fixed nitrogen is stable, and a fully oxidized phase with abundant nitrate. We infer that, in the process of oxidizing the early Proterozoic ocean, the system had to go through a nitrogen-limited phase during which time export production was severely attenuated. Our studies suggest that the presence of shallow seas with increased organic matter burial was a critical factor determining the concentration of oxygen in the ocean and atmosphere, while the phosphate concentration played a key role in determining the rate of oxygenation of the deep ocean.
\end{abstract}

INTRODUCTION

The evolution of oxygenic photosynthesis in the late Archean or early Proterozoic eon ultimately led to the rise of oxygen in Earth's atmosphere and ocean. However, there appears to have been an extraordinary delay of several hundred million years between the rise of oxygenic photosynthesis (before $2700 \mathrm{Ma}$; Summons and others, 1999; Brocks and others, 1999) and the accumulation of oxygen in the atmosphere (not until $2300 \mathrm{Ma}$; Farquhar and others, 2000; Bekker and others, 2004). The deep ocean remained anoxic for several hundred million years longer (Holland, 1984; Canfield, 1998; Anbar and Knoll, 2002).

Oxygenation has been conceptualized as a three-stage process (Walker and others, 1983; Kasting and others, 1992). In the first, reducing stage during the Archean, the ocean-atmosphere system was essentially free of oxygen except for trace amounts derived from high energy photolysis of water coupled to hydrogen escape to space (Catling and others, 2001). Even after the advent of oxygenic photosynthesis free oxygen levels in the atmosphere would have remained low for as long as the supply of reduced substances $\left(\mathrm{H}_{2}, \mathrm{CO}, \mathrm{H}_{2} \mathrm{~S}\right.$ from volcanoes and $\mathrm{Fe}^{2+}$ from hydrothermal inputs at oceanic ridges) exceeded the net production of oxygen (Holland, 1994), except in localized microenvironments in the ocean (for example, in stromatolitic mats; Buick,

*Institute of Marine and Coastal Sciences and Department of Geological Sciences, Rutgers University, 71 Dudley Road, New Brunswick, New Jersey 08901, USA; kfennel@marine.rutgers.edu

**Department of Earth and Planetary Science, Massachusetts Institute of Technology, 77 Massachusetts Avenue, Cambridge, Massachusetts 02139, USA 
1992). At some point during the Archean or early Proterozoic, either the supply of reduced substances decreased or net oxygen production increased, or both, such that oxygen began to accumulate in the atmosphere and surface ocean, while the deep ocean remained anoxic. This simultaneous presence of an oxidized surface and reduced deep ocean signifies stage two. Data from red beds (Chandler, 1980), cyanobacterial microfossils (Knoll, 1996), detrital mineral deposits (Des Marais and others, 1992), biomarkers (Summons and others, 1999; Brocks and others, 1999) and sulfur isotopes (Farquhar and others, 2000; Bekker and others, 2004) indicate that the second stage had began by $2300 \mathrm{Ma}$.

The third stage is characterized by an oxidized deep ocean and was probably initiated by a decrease in the supply of reductants to the deep sea and/or a further increase in the rate of oxygen production. Transition from the second to the third stage has conventionally been assumed to coincide with the disappearance of banded iron formations (BIFs) - the formation of which requires anoxic deep water-at 1800 Ma (Holland, 1984). In a different interpretation based on Proterozoic sulfur isotope data, Canfield (1998) suggests that the BIFs disappeared due to rising sulfide levels and that the deep ocean remained anoxic until about $800 \mathrm{Ma}$ (Canfield and Teske, 1996). Recent molybdenum isotope data supports this view (Arnold and others, 2004). Despite these different interpretations of when the deep ocean became oxidized, it appears that it did remain anoxic for several hundred million years (Myr) after oxygenic photosynthesis became established.

The accumulation of oxygen in the atmosphere is generally thought to have resulted from permanent burial of organic matter (see, for example, Des Marais and others, 1992). An alternative and not mutually exclusive hypothesis involves the escape of hydrogen to interplanetary space (Catling and others, 2001; Holland, 2002). Catling and co-workers suggested that methane photolysis in the upper atmosphere coupled with hydrogen escape to space increased the oxidation state of the atmosphere. However, this mechanism does not explain the large change in isotopic composition of carbonates at the time, which is consistent with burial of organic carbon in the lithosphere (Des Marais and others, 1992). Regardless of the mechanism, a gradual increase of the overall oxidation state of the mantle would have decreased the supply of reductants to the ocean and atmosphere (Holland, 2002).

In discussions of why the deep ocean remained anoxic for so long, the geochemistry of carbon, sulfur and iron are generally considered, and a shift in the balance between the influx of reductants to the deep ocean and the rate of oxygen supply is invoked. Nitrogen cycling-although highly relevant to the rate of net oxygen production-is generally ignored. In a discussion of the evolution of the nitrogen cycle, Falkowski (1997) suggested that with oxygen becoming available in the early Proterozoic: (i) the balance between $\mathrm{N}_{2}$ fixation and denitrification would have shifted toward denitrification, and (ii) the decrease in the availability of iron would have diminished $\mathrm{N}_{2}$ fixation. Both of these environmental changes would have contributed to a reduction of the fixed inorganic nitrogen inventory in the ocean, resulting in a limitation of photoautotrophic production, and, hence, a slowdown of oxygen evolution. Limitation of $\mathrm{N}_{2}$ fixation by trace metals in a sulfidic ocean after the disappearance of BIFs was further contemplated by Anbar and Knoll (2002). Here we explore the possibility that feedbacks between the nitrogen, oxygen and carbon cycles posed a major constraint on oxygenating the deep ocean by changing the balance between $\mathrm{N}_{2}$ fixation and denitrification.

Over 99 percent of the nitrogen on Earth's surface is $\mathrm{N}_{2}$ gas, which must be reduced to the level of ammonium in order to be assimilated by organisms for protein synthesis. The reduction is biochemically catalyzed by nitrogenases, a heterodimeric group of closely related enzymes found in a small number of taxonomically diverse 
procaryotes. Nitrogenases contain iron-sulfur clusters that are essential for catalytic activity. Upon exposure to molecular oxygen, the iron-sulfur clusters become oxidized and the enzyme is irreversibly inhibited. Numerous strategies have evolved to protect nitrogenase from exposure to molecular oxygen; all strategies ultimately decrease the efficiency of the process. Nonetheless, once ammonium is formed, in the presence of molecular oxygen it is oxidized by nitrifying bacteria to form nitrite and nitrate. Denitrification, resulting from the anaerobic reduction of nitrate by heterotrophic bacteria, regenerates $\mathrm{N}_{2}$. In the evolution of the nitrogen cycle, a feedback emerged when oxygenic photosynthesis led to the production of free oxygen. Whereas under anoxic conditions oceanic ammonium would have been relatively stable, with rising oxygen concentrations in the ocean, coupled nitrification-denitrification would have provided a conduit for the loss of fixed nitrogen from the oceans in a sub- or anoxic water column, and in reducing sediment environments. Hence a paradox emerges: if the anoxic/oxic transition led to a loss of fixed nitrogen from the oceans, how did oxygenic photoautotrophs continue to supply molecular oxygen without a supply of an essential nutrient?

To examine the dynamic interactions between the nitrogen, oxygen and carbon cycles, we have developed a simple box model that incorporates the fundamental features of biogeochemistry, ocean circulation and ocean-atmosphere gas-exchange.

MODEL CONCEPT AND DESCRIPTION

\section{Concept}

Our model consists of 4 ocean boxes representing the continental shelf seas, the high and low latitude surface open ocean, a deep ocean reservoir, and the atmosphere (fig. 1). The biogeochemical parameterizations of the model describe the dynamic behavior of nitrate, ammonium, phosphate and oxygen concentrations in each of the ocean boxes (fig. 2). All of these tracers are subject to the same transport processes by a prescribed ocean circulation, and oxygen exchange between the surface ocean and atmosphere driven by differences in partial pressure.

The essential biogeochemical parameterizations in our model are biological export of organic matter from the surface ocean, remineralization at depth, and burial. Export production consumes fixed nitrogen (nitrate or ammonium) and phosphate in the surface ocean and produces oxygen in Redfield stoichiometry. If there is a deficit of fixed nitrogen relative to phosphate in the surface waters, $\mathrm{N}_{2}$ fixation occurs and increases the surface pool of ammonium. A fraction of exported organic matter is buried and the rest is remineralized following either the anaerobic or aerobic pathway, depending on the ambient oxygen concentration. In anoxic and suboxic waters remineralization is based on coupled nitrification/denitrification, resulting in a loss of fixed nitrogen from the ocean. With increasing oxygen concentrations the aerobic remineralization pathway becomes more important.

A central assumption of our model is that $\mathrm{N}_{2}$ fixation is metabolically more expensive compared to the assimilation of fixed forms of nitrogen. This assumption is based on the high energy demand of $\mathrm{N}_{2}$ fixation. (Note that although the reduction of $\mathrm{N}_{2}$ to $2 \mathrm{NH}_{3}$ is exothermic, the reaction requires a huge investment in activation energy to break the triple $\mathrm{N} \equiv \mathrm{N}$ bond.) Empirical evidence suggests that most extant nitrogen fixers can grow on fixed nitrogen compounds, and that nitrogenase synthesis is generally repressed by ammonium and is induced by depletion of fixed nitrogen substrates (Ohki and others, 1986, 1991). In the contemporary ocean a low N:P ratio of available nutrients selects for $\mathrm{N}_{2}$-fixing microorganisms (Karl and others, 2002).

While our model resolves the sources and sinks of fixed nitrogen $\left(\mathrm{N}_{2}\right.$ fixation, burial and denitrification), we have significantly (and purposefully) simplified the phosphorous cycle. The source of phosphorous (weathering) and sinks (adsorption 


\section{Atmosphere}

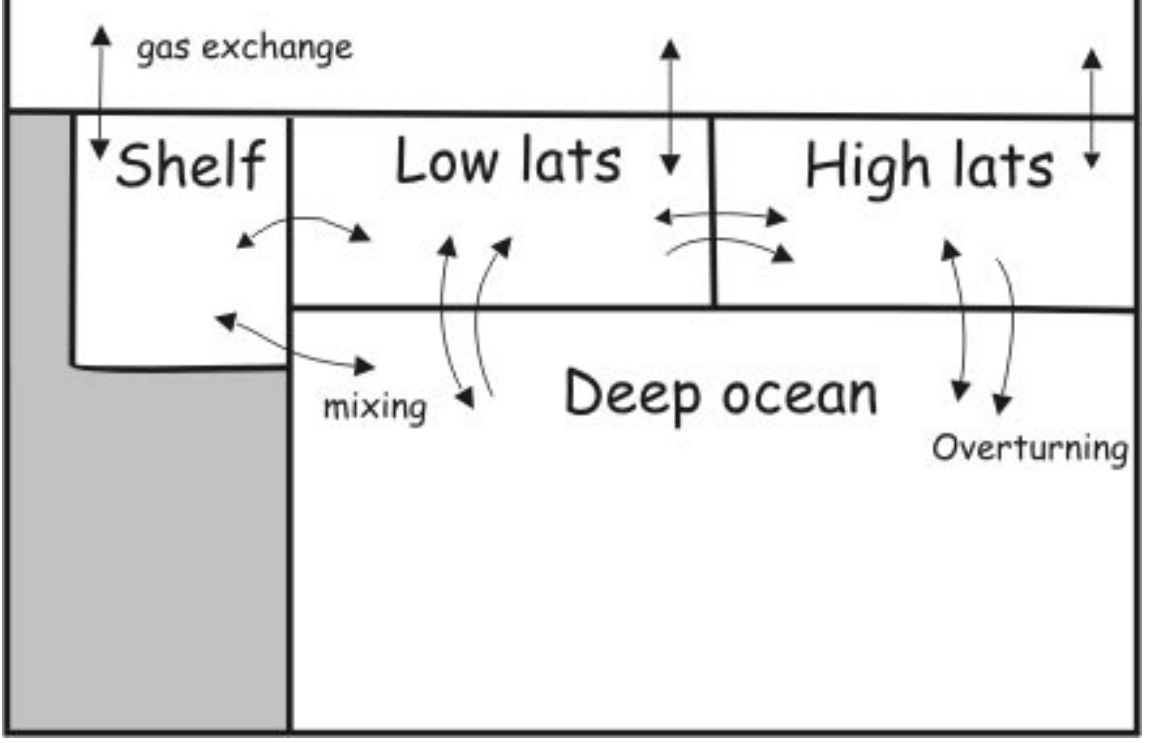

Fig. 1. Schematic depiction of the model configuration and transport schemes.

onto iron oxides and formation of apatite) are not included explicitly. The only loss of phosphorous in the model is through burial of organic matter, which we assume to be balanced by a continuous re-supply of phosphate, essentially conserving the total ocean phosphorus inventory. Oxygen sources and sinks, related to the production and remineralization of organic matter and nitrification, are resolved; however, other sinks of oxygen due to, for example, continental weathering and the oxidation of hydrothermal reductants, are not accounted for explicitly in this model. Although most of the presented simulations neglect external oxygen sinks such as the inflow of mantle reductants, we examine the effect of this flux in a final simulation by prescribing an external oxygen sink that decreases over time. While this treatment is clearly a simplification, it allows us to assess the effect of such unresolved oxygen sinks on nitrogen cycling.

Aspects of our model formulation have been used previously. For example, box models with a similar spatial set-up (a high latitude and low latitude surface ocean, a deep ocean and an atmosphere) have been used by Toggweiler and Sarmiento (1985) and Christensen (1994) in order to explore the partitioning of $\mathrm{CO}_{2}$ between the atmosphere and ocean during glacial and interglacial intervals. Toggweiler and Sarmiento (1985) focused on the relative roles of overturning circulation and biological carbon export in determining atmospheric $\mathrm{CO}_{2}$ levels. Christensen (1994) expanded their model by including a shallow continental shelf box and by considering nitrogen cycling and denitrification. Both studies explored only steady-state solutions to the model equations. There are parallels in the time-dependent representation of biogeochemical processes in the model presented here and that of Lenton and Watson 


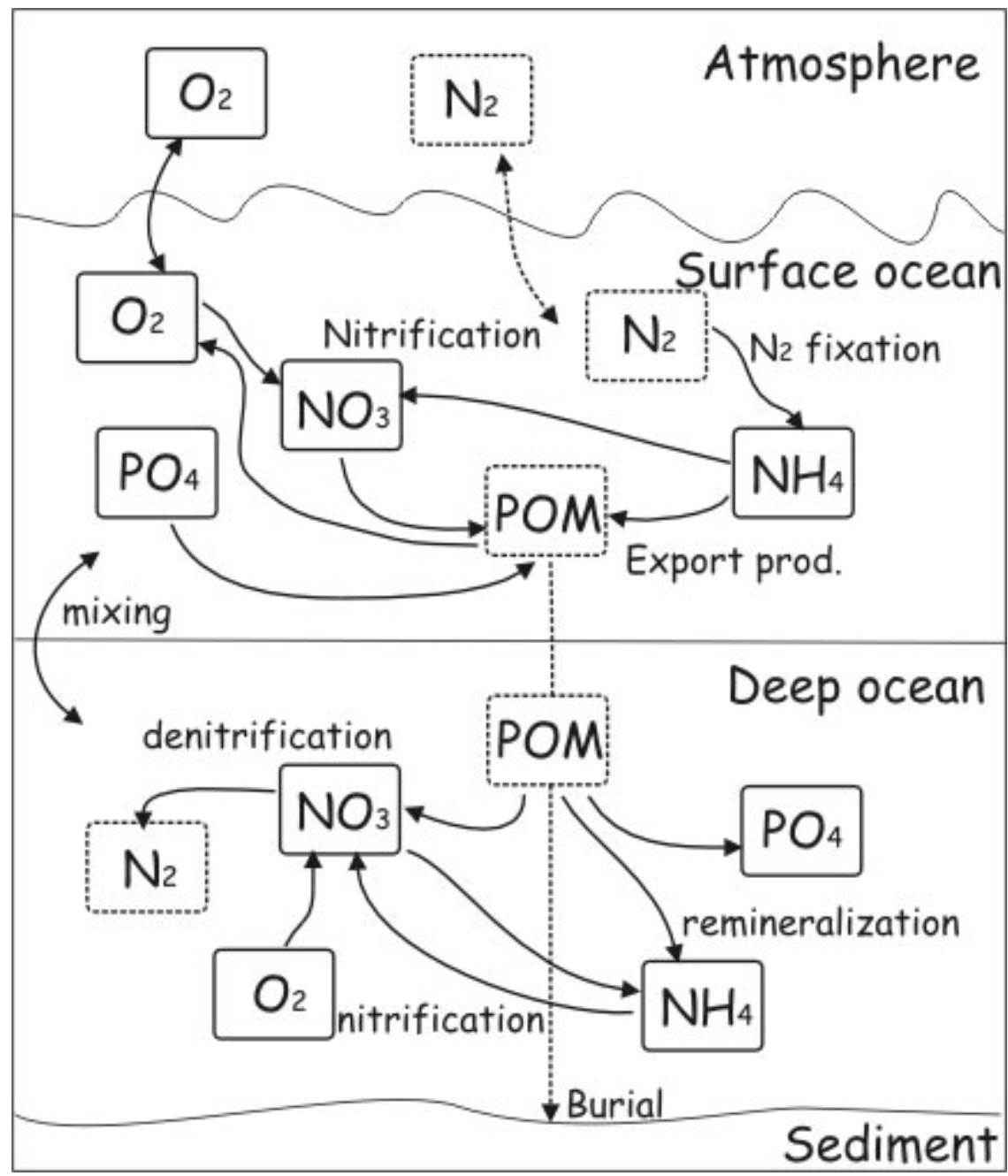

Fig. 2. Schematic of the biogeochemical processes included in our model.

(2000a, 2000b) who also considered the coupling between carbon, nitrogen, phosphorous and oxygen cycling. However, their model does not resolve any circulation processes or shallow shelves and, most significantly, does not explicitly represent ammonium and nitrification, which are necessary elements of our hypothesis.

Our model represents features commonly neglected in models of early oxygen evolution, in particular an oxygen-dependent nitrogen cycle, while simplifying factors that have been explored previously, for example, sulfur, iron and phosphorous cycling (see, for example, Holland, 1984; Canfield, 1998; Canfield and others, 2000). Likewise, we have simplified or excluded a number of biogeochemical processes, such as the feedback of oxygen on the efficiency of organic matter burial. Also, for the sake of heuristic simplicity, ocean circulation and mixing parameters and the phosphate inventory are imposed as constant values over the entire simulation period. The highly idealized nature of the model allows us to perform integrations of hundreds of millions of years duration, and to explore sensitivities to certain processes and parameters. 


\section{Parameterizations}

The model state variables are nitrate $\left(\mathrm{NO}_{3, i}\right)$, ammonium $\left(\mathrm{NH}_{4, i}\right)$, phosphate $\left(P_{4, i}\right)$ and oxygen $\left(O_{2, i}\right)$ concentrations defined in each of the ocean boxes $i(i=$ shelf, high latitude, low latitude, deep ocean), and the atmospheric oxygen mixing ratio, $\mathrm{AO}_{2}$. The time rate of change of the state variables is given by

$$
\frac{d \boldsymbol{C}}{d t}=\operatorname{mix}(\boldsymbol{C})+\operatorname{bgc}(\boldsymbol{C})+\operatorname{air}-\operatorname{sea}(\boldsymbol{C}),
$$

where $C$ is the vector of all state variables and mix, $b g c$, and air-sea are operators representing transport by ocean circulation, biogeochemical processes and air-sea exchange of oxygen, respectively.

Ocean advection and mixing are described by

$$
\operatorname{mix}\left(C_{i}\right)=\left[-k_{i j}\left(C_{i}-C_{j}\right)-k_{i k}\left(C_{i}-C_{k}\right)-k_{i l}\left(C_{i}-C_{l}\right)\right] / \text { vol }_{i},
$$

where $C_{i}$ is a tracer concentration in box $i, k_{i j}$ are the volume fluxes between boxes $i$ and $j$ associated with advection and mixing processes, vol $l_{i}$ is the volume of box $i$, and subscripts $i, j, k, l$ denote shelf, high and low latitude surface, and deep ocean boxes.

Export production is supported by fixed nitrogen and $\mathrm{N}_{2}$ fixation (export $=E_{1}+$ $\left.E_{2}\right)$. The fraction of export production based on fixed nitrogen $\left(E_{1}\right)$ is parameterized by a prescribed maximum export rate, $\mu_{1}$, and limited by either fixed nitrogen or phosphate depending on their relative abundances:

$$
E_{1}(i)=\mu_{1} \cdot P O_{4, i} \cdot \min \left(P O_{4, i} /\left(k_{P}+P O_{4, i}\right),\left(N O_{3, i}+N H_{4, i}\right) /\left(k_{N}+N O_{3, i}+N H_{4, i}\right)\right) .
$$

$k_{P}$ and $k_{N}$ are the half-saturation concentrations for the uptake of phosphate and fixed nitrogen, respectively. Production based on $\mathrm{N}_{2}$ fixation $\left(E_{2}\right)$ only occurs when fixed nitrogen concentrations are low in terms of absolute values $\left(\mathrm{NO}_{3, i}+\mathrm{NH}_{4, i}<1 \mu \mathrm{M}\right)$ and with respect to available phosphate $\left(\left(\mathrm{NO}_{3, i}+\mathrm{NH}_{4, i}\right) / \mathrm{PO}_{4, i}<16\right)$. In this case

$$
E_{2}(i)=\mu_{2} \cdot P O_{4, i} \cdot P O_{4, i} /\left(k_{P}+P O_{4, i}\right) .
$$

Note that the maximum rate of production based on $\mathrm{N}_{2}$ fixation, $\mu_{2}$, is smaller than $\mu_{1}$ to account for its higher metabolic cost. This parameterization of export production essentially follows Fennel and others (2002). Production occurs in all surface boxes ( $i=$ shelf, high and low latitude surface) and reduces the surface pools of nitrogen and phosphate according to Redfield stoichiometry. Consumption of nitrogen is divided between nitrate and ammonium in proportion to their relative abundance. Oxygen production is described by

$$
\begin{aligned}
O_{2} \operatorname{prod}(i)=R_{O: P\left(N O_{3}\right)} \cdot E_{1} \cdot N O_{3 i} / & \left(N O_{3, i}+N H_{4, i}\right) \\
& +R_{O: P\left(N H_{4}\right)} \cdot E_{1} \cdot N H_{4, i} /\left(N O_{3, i}+N H_{4, i}\right)+R_{O: P\left(N H_{4}\right)} \cdot E_{2}
\end{aligned}
$$

where $R_{O: P\left(\mathrm{NO}_{3}\right)}$ and $R_{O: P\left(\mathrm{NH}_{4}\right)}$ are oxygen-to-phosphorus ratios for the photosynthetic production of organic matter based on nitrate or ammonium, respectively.

Organic matter produced in the surface boxes is instantaneously exported, remineralized and buried. Remineralization of phosphate in the deep ocean follows

$$
\mathrm{PO}_{4} \operatorname{remin}(\text { deep })=\left(1-f_{\text {bur }}\right) \cdot\left(\operatorname{vol}_{\text {high }} \cdot \operatorname{export}(\text { high })+\operatorname{vol}_{\text {low }} \cdot \operatorname{export}(\text { low })\right) / \text { vol }_{\text {deep }},
$$

with the burial fraction $f_{\text {bur }}=\exp \left(-\Delta z(d e e p) / z^{*}\right)$ which assumes an exponential vertical profile for the decay of organic matter with $z^{*}$ as the length scale. Nitrogen remineralization is partitioned between the aerobic and anaerobic pathway depending on the anoxic fraction, $f_{\text {anox }}$, which represents the volume fraction of the deep ocean that is suboxic or anoxic. We parameterize the suboxic/anoxic fraction as an exponential 
function of the deep oxygen concentration $\left(f_{\text {anox }}=\exp \left(-O_{2 \text {, deep }} / k_{\text {anox }}\right)\right)$. While the form of this parameterization is unconstrained, it seems likely that the volume of anoxic waters is related to the mean deep ocean oxygen concentration. In the oxic fraction, $\left(1-f_{\text {anox }}\right)$, of the deep ocean, remineralization consumes and regenerates nitrate. In the suboxic or anoxic fraction, $f_{\text {anox }}$, ammonium is regenerated and nitrate is consumed. If nitrate concentrations are too low to support anaerobic remineralization, we assume that the oxidation of organic matter is facilitated by other electron donors, for example, sulphate. Thus organic matter can always be oxidized in the model, though the active oxidant may vary. The parameterizations of aerobic and anaerobic nitrogen remineralization then follow as

$$
\begin{aligned}
\mathrm{NO}_{3} \operatorname{remin}(\text { deep })=\left(1-f_{\text {bur }}\right) \cdot\left(1-f_{\text {anox }}\right) \cdot R_{\mathrm{N}: P} \cdot\left(\operatorname{vol}_{\text {high }} \cdot \operatorname{export}(\text { high })\right. & \\
& \left.+\operatorname{vol}_{\text {low }} \cdot \operatorname{export}(\text { low })\right) / \text { vol }_{\text {deep }}
\end{aligned}
$$

and

$$
\mathrm{NH}_{4} \operatorname{remin}(\text { deep })=\left(1-f_{\text {bur }}\right) \cdot f_{\text {anox }} \cdot R_{N: P} \cdot\left(\operatorname{vol}_{\text {high }} \cdot \operatorname{export}(\text { high })+\operatorname{vol}_{\text {low }} \cdot \operatorname{export}(\text { low })\right) / \text { vol }_{\text {deep }},
$$

respectively. The consumption of oxygen and nitrate during the remineralization of organic matter is described as

$$
\mathrm{O}_{2} \operatorname{sink}(\operatorname{deep})=R_{O: P\left(\mathrm{NO}_{3}\right)} / R_{\mathrm{N}: P} \cdot \mathrm{NO}_{3} \operatorname{remin}(\text { deep })
$$

and

$$
\mathrm{NO}_{3} \operatorname{sink}(\text { deep })=R_{\mathrm{NO}_{3} \text { denit }} \cdot \mathrm{NH}_{4} \operatorname{remin}(\text { deep }) .
$$

Remineralization and burial are treated analogously in the shelf box. Nitrification of ammonium to nitrate is limited by the availability of oxygen according to

$$
\text { nitri( } i)=\mu_{\text {nitri }} \cdot \mathrm{NH}_{4} \cdot \mathrm{O}_{2, i} /\left(k_{O}+\mathrm{O}_{2, i}\right),
$$

where $\mu_{\text {nitri }}$ and $k_{O}$ are the maximum nitrification rate and half-saturation concentration, respectively, in all ocean boxes.

Gas exchange of oxygen between the surface ocean and atmosphere is parameterized simply as a Newtonian damping towards the saturation concentration, that is

$$
\mathrm{O}_{2} \operatorname{exch}(i)=\left(\mathrm{oeq}-\mathrm{O}_{2, i}\right) / \tau,
$$

assuming that the equilibrium concentration, oeq, scales linearly with the atmospheric oxygen mixing rate as $o e q=o e q_{\text {present }} \cdot \mathrm{AO}_{2} / 0.21$. The damping timescale, $\tau$, is on the order of one year.

The model is integrated using a Runge-Kutta solver with adaptive stepsize control (Press and others, 2002).

\section{RESULTS AND DISCUSSION}

We first consider the results of a set of sensitivity simulations where the configuration of the model's ocean-atmosphere system was held constant over the course of each simulation (that is, all model parameters were constant) but multiple simulations with different choices for model parameters were performed (for example, different values for the phosphate inventory, shelf size et cetera). Comparison of these simulations allows us to identify the model's principal modes of behavior. All simulations were initiated under anaerobic conditions with no free oxygen in the atmosphere or ocean, without nitrate in the ocean, and with an initially uniform ammonium concentration of $0.1 \mu \mathrm{M}$. The model was integrated for $50 \mathrm{Myr}$ with the parameter values given in 
TABLE 1

Model parameters and initial conditions for the standard simulation. The initial phosphate concentration of $0.2 \mu \mathrm{M}$ is the inferred Proterozoic value from Bjerrum and Canfield (2002).

\begin{tabular}{|c|c|c|}
\hline Parameter & Symbol & Value \\
\hline Volume of the high latitude box & $v_{\text {vol }}$ high & $9.0 \times 10^{15} \mathrm{~m}^{3}$ \\
\hline Volume of the low latitude box & vol low $_{\text {low }}$ & $9.0 \times 10^{15} \mathrm{~m}^{3}$ \\
\hline Volume of the deep ocean box & vol $_{\text {deep }}$ & $8.1 \times 10^{17} \mathrm{~m}^{3}$ \\
\hline Volume of the shelf box & vol $_{\text {shelf }}$ & $1.5 \times 10^{15} \mathrm{~m}^{3}$ \\
\hline Initial phosphate concentration & $P O_{4, i}(\mathrm{t}=0)$ for all boxes $i$ & $0.2 \mu \mathrm{M}$ \\
\hline Initial nitrate concentration & $N O_{3, i}(\mathrm{t}=0)$ for all boxes $i$ & $0.0 \mu \mathrm{M}$ \\
\hline Initial ammonium concentration & $N H_{4, i}(\mathrm{t}=0)$ for all boxes $i$ & $0.1 \mu \mathrm{M}$ \\
\hline Initial oxygen concentration & $O_{2, i}(t=0)$ for all boxes $i$ & $0.0 \mu \mathrm{M}$ \\
\hline Initial atmospheric oxygen & $\mathrm{AO}_{2}(\mathrm{t}=0)$ & $0 \%$ \\
\hline Mixing between high latitude and deep boxes & $k_{h d}$ & $50 \mathrm{~Sv}$ \\
\hline Mixing between low latitude and deep boxes & $k_{l d}$ & $30 \mathrm{~Sv}$ \\
\hline Mixing between low and high latitude boxes & $k_{l h}$ & $30 \mathrm{~Sv}$ \\
\hline Mixing between deep and shelf boxes & $k_{d s}$ & $5 \mathrm{~Sv}$ \\
\hline Mixing between low latitude and shelf boxes & $k_{l s}$ & $5 \mathrm{~Sv}$ \\
\hline Maximum rate of export production & $\mu_{l}$ & $1 \mathrm{yr}^{-1}$ \\
\hline $\begin{array}{l}\text { Half-saturation concentration for phosphate } \\
\text { uptake }\end{array}$ & $k_{P}$ & $0.1 \mu \mathrm{M}$ \\
\hline $\begin{array}{l}\text { Half-saturation concentration for nitrogen } \\
\text { uptake }\end{array}$ & $k_{N}$ & $1.6 \mu \mathrm{M}$ \\
\hline Maximum rate of $\mathrm{N}_{2}$ fixation & $\mu_{2}$ & $0.2 \mathrm{yr}^{-1}$ \\
\hline $\begin{array}{l}\text { Vertical length scale for remineralization of } \\
\text { organic matter }\end{array}$ & $z^{*}$ & $300 \mathrm{~m}$ \\
\hline Denitrification parameter & $k_{\text {anox }}$ & $10 \mu \mathrm{M}$ \\
\hline Maximum nitrification rate & $\mu_{\text {nitri }}$ & $6 \mathrm{yr}^{-1}$ \\
\hline Half-saturation concentration of nitrification & $k_{O}$ & $20 \mu \mathrm{M}$ \\
\hline $\begin{array}{l}\text { O:P stoichiometry for the production of } \\
\text { organic matter based on nitrate }\end{array}$ & $R_{O: P(N O 3)}$ & 138 \\
\hline $\begin{array}{l}\text { O:P stoichiometry for the production of } \\
\text { organic matter based on ammonium }\end{array}$ & $R_{O: P(N H 4)}$ & 102 \\
\hline $\begin{array}{l}\mathrm{N}: \mathrm{P} \text { stoichiometry for the production of } \\
\text { organic matter }\end{array}$ & $R_{N: P}$ & 6.625 \\
\hline $\mathrm{NO}_{3}: \mathrm{P}$ stoichiometry for denitrification & $R_{\text {NO3denit }}$ & 84.8 \\
\hline $\begin{array}{l}\text { Present ocean oxygen equilibrium } \\
\text { concentration }\end{array}$ & oeq $q_{\text {present }}$ & $0.2 \mathrm{~mol} \mathrm{~m}^{-3}$ \\
\hline $\begin{array}{l}\text { Timescale of atmosphere-ocean exchange of } \\
\text { oxygen }\end{array}$ & $\tau$ & $1 \mathrm{yr}$ \\
\hline
\end{tabular}

table 1 unless otherwise noted. After presenting the model's sensitivity we discuss forced simulations of $200 \mathrm{Myr}$ duration where the spatial extent of the model's shallow shelf seas changes over time. In these simulations we explore the effects of eustatic sea 

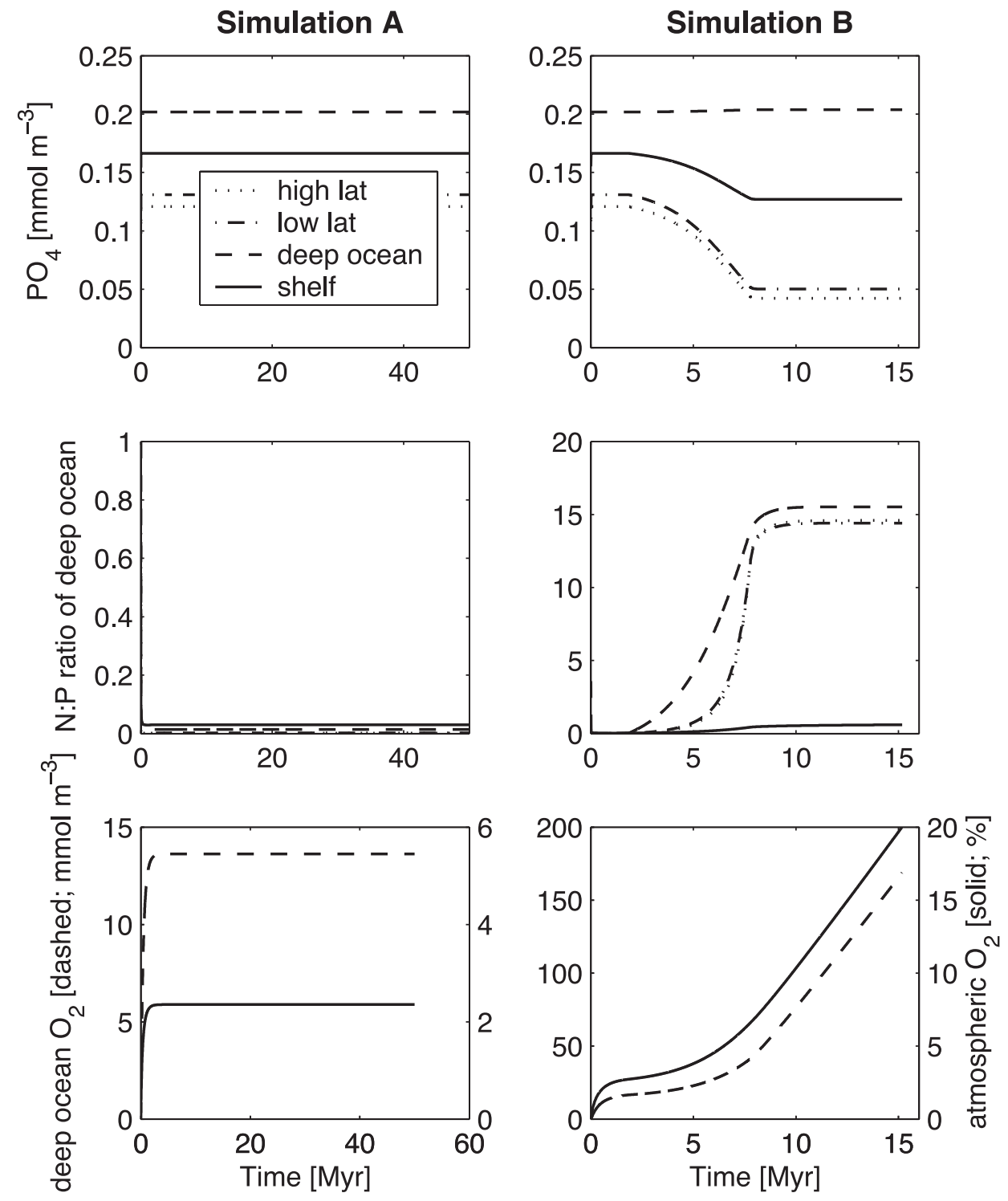

Fig. 3. Model simulated $\mathrm{PO}_{4}$ concentrations (top) and N:P ratio (middle) in the four ocean boxes, and deep ocean oxygen and atmospheric oxygen concentrations (bottom). Both simulations use the standard parameter set given in table 1 and only differ in the width of the shelf box, which is set to $200 \mathrm{~km}$ in simulation A (left panels) and $400 \mathrm{~km}$ in simulation B (right panels).

level changes on organic matter burial and oxygen evolution. Finally, we discuss the effect of an external supply of reductants in modulating the simulated course of the oxygenation process.

\section{Two Principal Modes of Model Behavior}

First we compare two simulations, the configurations of which differ only in the spatial extent of the shallow shelf box. Simulation A and B have a shelf width of $200 \mathrm{~km}$ and $400 \mathrm{~km}$, respectively. The model results (shown in fig. 3) differ dramatically. In 
simulation A the system moves into a steady state with a negligible amount of fixed nitrogen in the ocean and low concentrations of oxygen in the ocean and atmosphere. In simulation B the level of fixed nitrogen in the ocean stays low for only about 5 Myr. Then fixed nitrogen levels increase until the phosphate inventory is matched at about Redfield ratio proportions, and the ocean and atmosphere quickly become oxygenated (present day atmospheric oxygen levels are reached within $15 \mathrm{Myr}$ ). In both simulations the initially available ammonium is quickly removed from the ocean through nitrification and subsequent denitrification. As oxygen becomes available through the production and burial of organic matter, ammonium is nitrified to nitrate, which is then denitrified and lost from the system, and the ocean becomes essentially void of any fixed nitrogen as evidenced by the small N:P ratio. As a result of this decrease, export production becomes nitrogen limited and is diminished as can be seen in the weakening of the vertical gradient in phosphate (fig. 3). The ammonium concentrations in the deep ocean are about $2 \times 10^{-4} \mu \mathrm{M}$ and nitrate concentrations are about $2 \times 10^{-3} \mu \mathrm{M}$ in both simulations during this period of severe nitrogen limitation. The deep ocean remains anoxic during this period, and atmospheric and surface ocean oxygen levels remain low with concentrations of about $10 \mu \mathrm{M}$ and 2 percent, respectively (fig. 3). Export production depends entirely on $\mathrm{N}_{2}$ fixation to satisfy nitrogen demands and the rate of net oxygen production is low because the produced oxygen is almost completely removed during nitrification. In simulation B there is a small net gain of oxygen over time (about $2 \mu \mathrm{M}$ per Myr in the deep ocean), but in simulation A the system gets trapped in the low-nitrogen state with a low constant oxygen concentration and remains there. In other words, the system is locked into a low nitrogen, low oxygen stable state in which the sources and sinks of nitrogen and oxygen are in balance.

How can a balance between the sources and sinks of nitrogen and oxygen be achieved, despite the continued production of organic matter? Let us consider the stoichiometric gain and loss of oxygen during the production and mineralization of 1 mol of organic matter. The production of 1 mol organic matter yields between 102 and 139 mol of oxygen depending on the source of fixed nitrogen (ammonium or nitrate). In the aerobic mineralization of $1 \mathrm{~mol}$ organic matter, between 102 and $138 \mathrm{~mol}$ of oxygen are required depending on the nitrogen product (ammonium or nitrate). Assuming that the same form of fixed nitrogen is used in the production of organic matter as is produced in its oxidation, it becomes clear that a net gain of oxygen only occurs if some organic matter escapes oxidation through burial. Since some burial of organic matter occurs throughout our simulations, there is always a net production of oxygen for the oxidized ocean. However, in the mineralization of $1 \mathrm{~mol}$ organic matter via the anaerobic or denitrification pathway $84.8 \mathrm{~mol}$ nitrate are required instead of oxygen. The $84.8 \mathrm{~mol}$ nitrate must have been produced by nitrification of ammonium, which, in turn, required 169.6 moles of oxygen-more oxygen than was gained in the production of $1 \mathrm{~mol}$ of organic matter. Hence, a net decrease or a stasis in oxygen evolution can occur, depending on the balance between burial of organic matter and the relative contributions of aerobic and anaerobic remineralization of organic matter. The relative contribution of aerobic and anaerobic remineralization is set by the relative volumes of oxic and suboxic/anoxic waters in the ocean.

In simulation $\mathrm{B}$ a critical threshold is reached at which nitrate starts to accumulate leading to an increase in organic matter export and net oxygen production and ultimately to the oxygenation of ocean and atmosphere (fig. 3). This critical point is determined by the oxygen concentration at which the rates of nitrification and denitrification are equal (as illustrated in fig. 4). Both nitrification and denitrification are functions of oxygen. As oxygen concentrations increase, the nitrification rate increases and the denitrification rate decreases (fig. 4). At low oxygen concentrations 


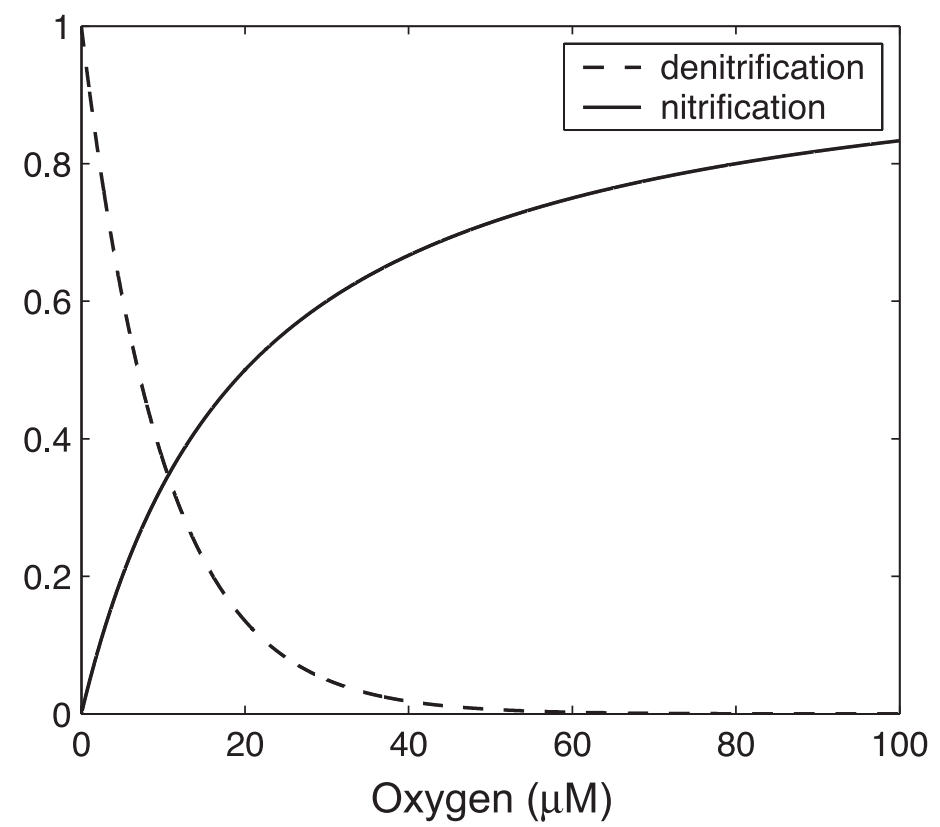
tion.

Fig. 4. Normalized nitrification and denitrification rates as a function of dissolved oxygen concentra-

the denitrification rate exceeds nitrification, hence all produced nitrate is denitrified. Only when oxygen levels increase to the point where nitrification exceeds denitrification (at $11 \mu \mathrm{M} \mathrm{O}_{2}$ for the normalized rates shown in fig. 4), does nitrate accumulate. In simulation A, a critical ratio between aerobic and anaerobic mineralization without net oxygen production is reached before nitrification exceeds denitrification. Hence the system gets locked in the low nitrogen, low oxygen state. In simulation B net oxygen production is sufficient to push the model into the regime, which favors nitrification and further oxygenation.

Simulations A and B illustrate the two qualitatively different stable states the model system can attain. The first is a low nitrogen, low oxygen steady state at which oceanic nitrogen and oxygen levels remain constant over time. The second is an oxygenated state at which the oceanic inventory of fixed nitrogen matches the phosphate inventory in Redfield proportion and net oxygen production occurs.

\section{Model Sensitivity}

The rate of oxygenation of the ocean and atmosphere in our model is strongly determined by the size of the continental shelf box (fig. 3). This dependency results from the higher burial efficiency of organic matter on the shallow continental shelf, which leads to higher net oxygen production. Without burial, oxygen evolution during the photosynthetic production of organic matter would be balanced by oxygen consumption during its mineralization. The distribution of organic matter in the water column is determined by the mineralization of sinking matter and is well approximated by an exponential decay function with depth (Suess, 1980; Martin and others, 1987). Consequently, the fraction of exported organic matter that reaches the sea floor and can be buried is a function of the depth of the water column. Our model calculates the burial fraction of organic matter based on this exponential decay with a given 
e-folding scale. Burial of organic matter in our model is hence more efficient on the shallow continental shelves than in the deep ocean. A relative increase in shelf area thus leads to an increase in organic matter burial and consequently in net oxygen production. In the narrow shelf case (simulation A; $200 \mathrm{~km}$ ) the ocean gets locked in a steady state in which neither oxygen nor fixed nitrogen levels increase. In this case the fixation of nitrogen is balanced by denitrification and net oxygen production is zero. In case of a wider shelf (simulation B; $400 \mathrm{~km}$ ) the relative increase in organic matter burial is sufficient to overcome the nitrification-denitrification sink.

Let us now examine sensitivity to the phosphate inventory, the denitrification and nitrogen fixation parameters, and vertical mixing by perturbing each of these parameters from their "standard" values for both cases discussed above, that is, for a shelf width of $200 \mathrm{~km}$ and a shelf width of $400 \mathrm{~km}$ (see list in table 2). The sensitivity in the model is assessed by comparing the steady state concentration of atmospheric oxygen in cases where a steady state is reached, and the duration until atmospheric oxygen levels reach 20 percent in cases where the systems becomes oxygenated (figs. 5A and $5 \mathrm{~B})$.

In the case of the narrow shelf, perturbation of denitrification, $\mathrm{N}_{2}$-fixation and mixing parameters produce relatively small changes in the steady state concentration of atmospheric oxygen (fig. 5A). With the exception of vertical mixing, an increase of the parameter value leads to small increases of the oxygen concentration. However, an increase in phosphate concentration to the present day level has a more pronounced effect, increasing steady state oxygen by an order of magnitude. In the case of a wide shelf, an increase of the phosphate inventory to the present day level speeds up the oxygenation process from the predicted $15 \mathrm{Myr}$ in the standard case to less than $1 \mathrm{Myr}$ (fig. 5B). The decrease in phosphate inventory depresses oxygen evolution such that the system remains in the nitrogen limited state despite a $400 \mathrm{~km}$ wide shelf (fig. 5A). The model's sensitivity to differences in phosphate inventory can be best understood by illustrating the effect on the fixed nitrogen inventory. In both cases, the steady state and oxygenated case, the nitrogen inventory scales with the phosphate inventory (fig. 6 ). This relation is obvious for the oxidized ocean where the phosphate and the nitrogen inventories will be matched stoichiometrically with respect to the Redfield ratio. This stoichiometric match is maintained because $\mathrm{N}_{2}$ fixation will occur if the oceanic N:P ratio is below the Redfield ratio, but will cease when Redfield proportions are reached because $\mathrm{N}_{2}$-fixers are competitive only in a nitrogen-limited ocean. In the low oxygen state, nitrogen fixation and hence the nitrogen inventory will depend directly on both the phosphate inventory and the $\mathrm{N}_{2}$ fixation rate (that is, its efficiency). That is, for a constant $\mathrm{N}_{2}$ fixation rate an increase in the phosphate inventory leads to an increase in the nitrogen fixation flux and inventory. Changes in the $\mathrm{N}_{2}$ fixation rate lead to similar changes in the nitrogen inventory. In the case of a wide shelf an efficient $\mathrm{N}_{2}$ fixation speeds up oxygenation (fig. $5 \mathrm{~B}$ ), while an inefficient $\mathrm{N}_{2}$ fixation depresses oxygen evolution and the system remains in the low oxygen steady state.

These analyses demonstrate that changes in the areal extent of the continental shelf, the concentration of phosphate, and the efficiency of nitrogen fixation determine whether the system remains in a low nitrogen, low oxygen state.

\section{Forced Simulations}

We have seen that due to the non-linear interaction between export production, oxygen evolution, nitrification and denitrification the ocean-atmosphere system can have two dramatically different stable states, namely a low oxygen, low nitrogen state in which the photosynthesis and net oxygen production are depressed, and an oxidized state. Net oxygen production depends on factors like the ratio of export production to burial of organic matter, and the rate of oxygen consumption during nitrification, 
TABLE 2

Sensitivity experiments. (*) indicates that a low nitrogen, low oxygen steady state was reached

\begin{tabular}{|c|c|c|}
\hline $\begin{array}{l}\text { Parameter } \\
\text { varied }\end{array}$ & Simulations & $\begin{array}{c}\text { Parameter values } \\
\text { that differ from } \\
\text { standard }\end{array}$ \\
\hline \multirow[t]{4}{*}{ Shelf width } & Wider shelf & $400 \mathrm{~km}$ \\
\hline & Wider shelf* & $300 \mathrm{~km}$ \\
\hline & Standard parameter set * & $200 \mathrm{~km}$ \\
\hline & Narrower shelf $*$ & $100 \mathrm{~km}$ \\
\hline \multirow[t]{6}{*}{$\begin{array}{l}\text { Phosphate } \\
\text { inventory }\end{array}$} & $\begin{array}{l}\text { Larger initial } \mathrm{PO}_{4} \text { concentration and } 200 \mathrm{~km} \text { wide } \\
\text { shelf * }\end{array}$ & \multirow[t]{2}{*}{$2 \mu \mathrm{M}$} \\
\hline & $\begin{array}{l}\text { Larger initial } \mathrm{PO}_{4} \text { concentration and } 400 \mathrm{~km} \text { wide } \\
\text { shelf }\end{array}$ & \\
\hline & Standard parameter set and $200 \mathrm{~km}$ wide shelf * & \multirow{2}{*}{$0.2 \mu \mathrm{M}$} \\
\hline & Standard parameter set and $400 \mathrm{~km}$ wide shelf & \\
\hline & $\begin{array}{l}\text { Smaller initial } \mathrm{PO}_{4} \text { concentration and } 200 \mathrm{~km} \text { wide } \\
\text { shelf } *\end{array}$ & \multirow{2}{*}{$0.02 \mu \mathrm{M}$} \\
\hline & $\begin{array}{l}\text { Smaller initial } \mathrm{PO}_{4} \text { concentration and } 400 \mathrm{~km} \text { wide } \\
\text { shelf } *\end{array}$ & \\
\hline \multirow[t]{6}{*}{ Circulation } & Larger mixing and $200 \mathrm{~km}$ wide shelf & \multirow{2}{*}{$\begin{array}{l}k_{h d}=100 \mathrm{~Sv} \\
k_{l d}=k_{l h}=60 \mathrm{~Sv}\end{array}$} \\
\hline & Larger mixing and $400 \mathrm{~km}$ wide shelf* & \\
\hline & Standard parameter set and $200 \mathrm{~km}$ wide shelf * & \multirow{2}{*}{$\begin{array}{l}k_{h d}=50 \mathrm{~Sv} \\
k_{l d}=k_{l h}=30 \mathrm{~Sv}\end{array}$} \\
\hline & Standard parameter set and $400 \mathrm{~km}$ wide shelf & \\
\hline & Smaller mixing and $200 \mathrm{~km}$ wide shelf & \multirow{2}{*}{$\begin{array}{l}k_{h d}=25 \mathrm{~Sv} \\
k_{l d}=k_{l h}=15 \mathrm{~Sv}\end{array}$} \\
\hline & Smaller mixing and $400 \mathrm{~km}$ wide shelf & \\
\hline \multirow{6}{*}{$\begin{array}{c}\text { Denitrification } \\
\text { parameter }\end{array}$} & Larger denitrification and $200 \mathrm{~km}$ wide shelf * & \multirow{2}{*}{$k_{\text {anox }}=5 \mu \mathrm{M}$} \\
\hline & Larger denitrification and $400 \mathrm{~km}$ wide shelf & \\
\hline & Standard parameter set and $200 \mathrm{~km}$ wide shelf * & \multirow{2}{*}{$k_{\text {anox }}=10 \mu \mathrm{M}$} \\
\hline & Standard parameter set and $400 \mathrm{~km}$ wide shelf & \\
\hline & Smaller denitrification and $200 \mathrm{~km}$ wide shelf $*$ & \multirow{2}{*}{$k_{\text {anox }}=15 \mu \mathrm{M}$} \\
\hline & Smaller denitrification and $400 \mathrm{~km}$ wide shelf & \\
\hline \multirow{6}{*}{$\begin{array}{l}\mathrm{N}_{2} \text { fixation } \\
\text { parameter }\end{array}$} & Larger $\mathrm{N}_{2}$ fixation and $200 \mathrm{~km}$ wide shelf ${ }^{*}$ & \multirow{2}{*}{$\mu_{2}=0.3 \mathrm{yr}^{-1}$} \\
\hline & Larger $\mathrm{N}_{2}$ fixation and $400 \mathrm{~km}$ wide shelf & \\
\hline & Standard parameter set and $200 \mathrm{~km}$ wide shelf* & \multirow{2}{*}{$\mu_{2}=0.2 \mathrm{yr}^{-1}$} \\
\hline & Standard parameter set and $400 \mathrm{~km}$ wide shelf & \\
\hline & Smaller $\mathrm{N}_{2}$ fixation and $200 \mathrm{~km}$ wide shelf $*$ & \multirow{2}{*}{$\mu_{2}=0.1 \mathrm{yr}^{-1}$} \\
\hline & Smaller $\mathrm{N}_{2}$ fixation and $400 \mathrm{~km}$ wide shelf $*$ & \\
\hline
\end{tabular}

both of which can be affected by the model's spatial configuration and model parameters (for example, a large shallow shelf, a large phosphate inventory, and efficient $\mathrm{N}_{2}$ fixation favor oxygenation). At the oxic/anoxic transition the oceanatmosphere system likely moved through a phase of low nitrogen availability, and possibly got locked in the low nitrogen, low oxygen state for several hundred million years until at least one crucial factor changed to favor oxygenation. For example, changes in sea level and phosphate availability could have been the result of enhanced tectonic activity at the beginning and end of the Proterozoic (Braiser and Lindsay, 1998). 


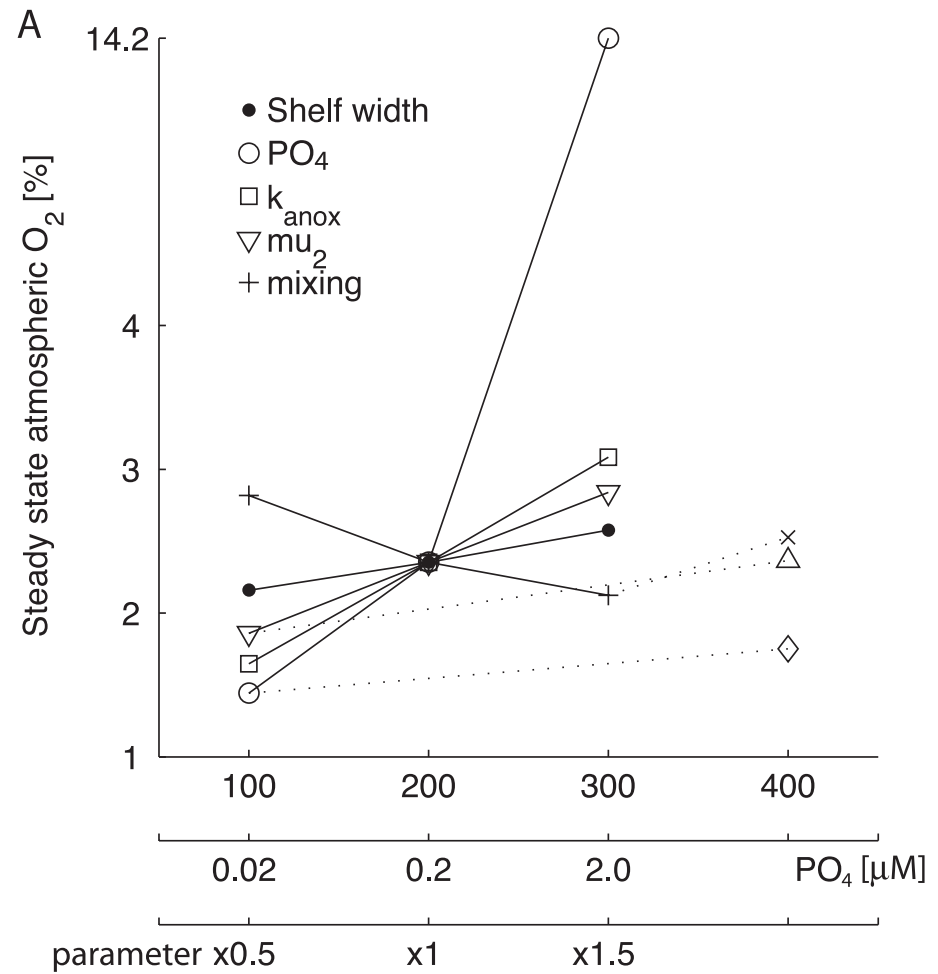

B

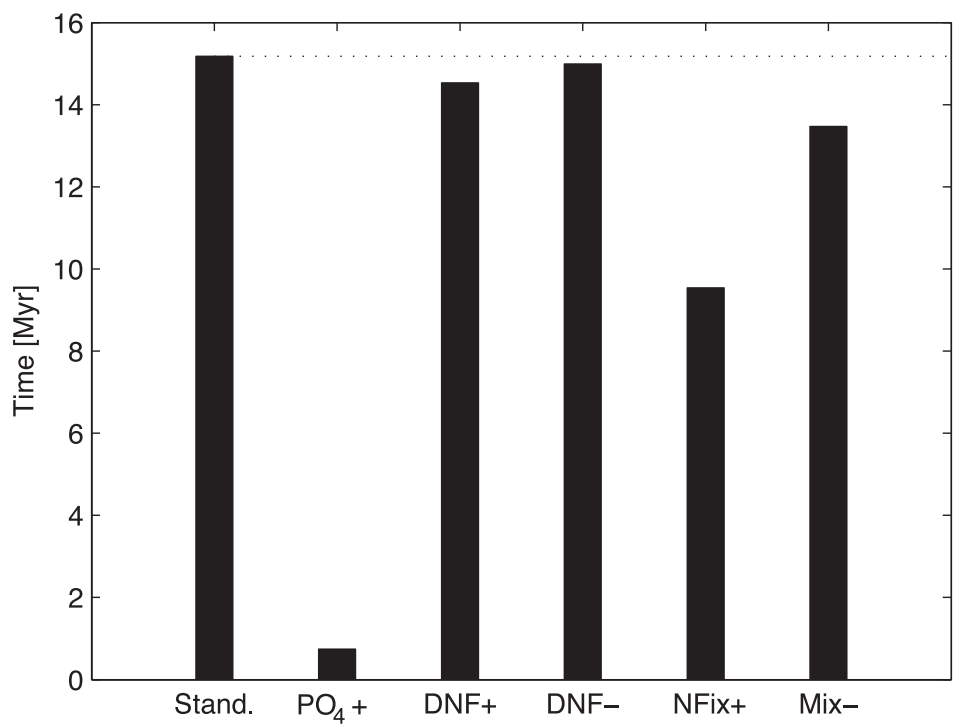

Fig. 5. (A) Steady state atmospheric oxygen concentration for sensitivity simulations in which a steady state is reached. (B) Predicted duration until $20 \%$ atmospheric oxygen is reached for sensitivity simulations in which the system becomes oxygenated. 


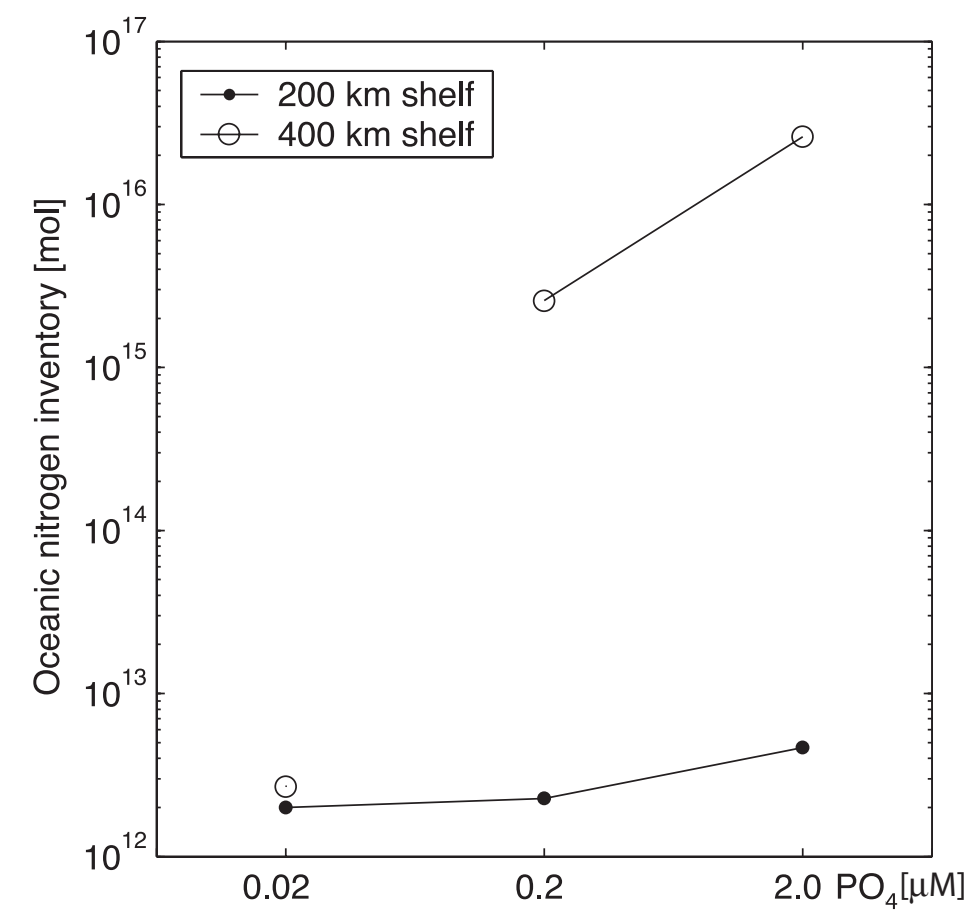

Fig. 6. Total oceanic inventory of fixed nitrogen for different phosphate inventories.

We performed three forced simulations where the shelf width changed over time. In the first simulation (F1) all parameters are chosen as in table 1, and the shelf width gradually increases from $100 \mathrm{~km}$ at the start of the simulation to $400 \mathrm{~km}$ after $100 \mathrm{Myr}$, followed by a gradual decrease (fig. 7). The second simulation (F2) uses the same parameters as in F1, but assumes that the shelf width increases only to $300 \mathrm{~km}$ width. The third simulation uses an increased phosphate inventory $(2 \mu \mathrm{M}$ instead of the 0.2 $\mu \mathrm{M}$ in F1 and F2), but the same history of shelf width as F2. The resulting evolution of the oceanic N:P ratio and the atmospheric oxygen concentration are given in figure 7 . In all three simulations the system is initially locked in the low nitrogen, low oxygen state (with different steady state levels of atmospheric oxygen). In F1 the increase of shelf width to $400 \mathrm{~km}$ results in a large enough increase of organic matter burial and oxygen production to push the system out of this state into oxygenation. However, an increase in shelf width to only $300 \mathrm{~km}$ is not sufficient as demonstrated in F2. Simulation F3 essentially repeats F2 but with an increased oceanic phosphate inventory. In this case the atmosphere and ocean become oxygenated as the shelf width approaches $250 \mathrm{~km}$. These results highlight the critical role of tectonic processes (sea-floor spreading rates), which control eustatic sea level and shallow shelf sea area, in determining the rate of oxygenation of the oceans.

\section{The Role of an External Oxygen Sink}

The simulations presented thus far have ignored the oxygen sink that arises from the oxidation of mantle reductants originating from volcanic activity and hydrothermal vents. To illustrate the implications of such an additional oxygen sink, we performed a simulation where we artificially impose a sink that initially removes 90 percent of the oxygen produced, decreases linearly to 30 percent after $100 \mathrm{Myr}$, and 
$\mathrm{F} 1\left(\mathrm{PO}_{4}=0.2 \mu \mathrm{M}\right)$
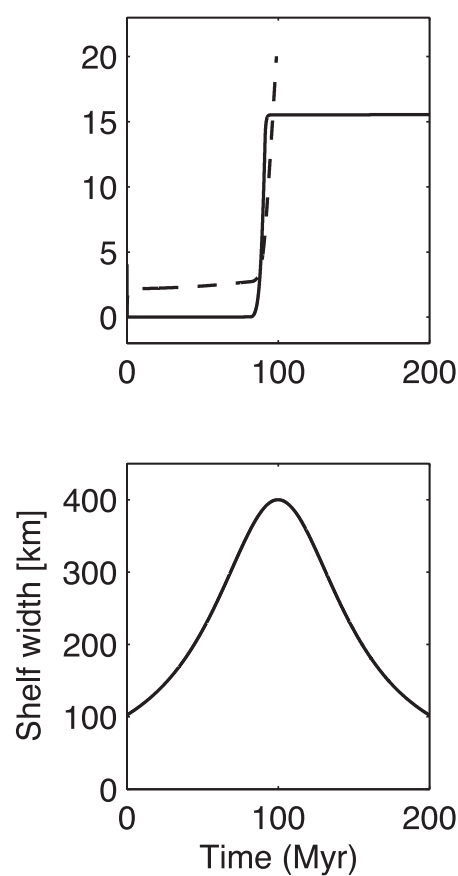

$\mathrm{F} 2\left(\mathrm{PO}_{4}=0.2 \mu \mathrm{M}\right)$

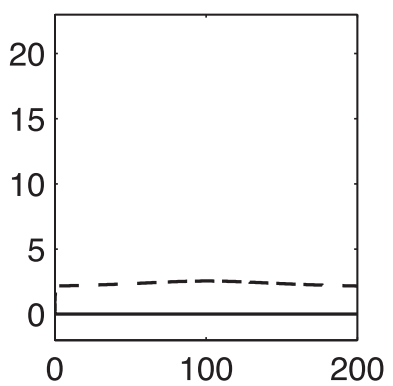

$\mathrm{F} 3\left(\mathrm{PO}_{4}=2 \mu \mathrm{M}\right)$

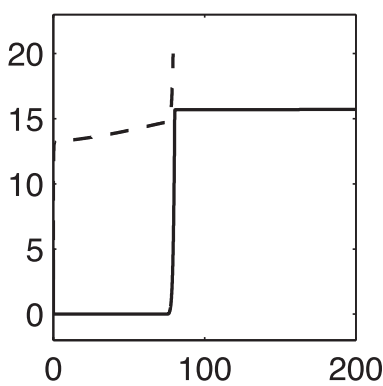

Fig. 7. Oceanic N:P ratio (top; solid line) and atmospheric oxygen in percent (top; dashed line) for different inventories of phosphate and temporally varying shelf width (bottom).

vanishes after $150 \mathrm{Myr}$. The model parameters are chosen as in table 1 and the shelf width is assumed to be $100 \mathrm{~km}$ initially and increases to $400 \mathrm{~km}$ after 500 Myrs. The predicted phosphate concentrations, deep ocean ammonium and nitrate concentrations, atmospheric and deep ocean oxygen, and the relative strengths of the different oxygen consuming processes are illustrated in figure 8 . In this simulation the oxygen consuming processes are organic matter remineralization, nitrification of ammonium, and the external oxygen sink representing mantle reductants.

For the first $30 \mathrm{Myr}$ while the external oxygen sink is in effect, fixed nitrogen is present in form of a steadily decreasing reservoir of ammonium (fig. 8). The deep ocean remains anoxic during this period and the atmospheric oxygen level is low with concentrations of 0.2 percent. The imposed, external oxygen sink is the dominant oxygen removal process during this time (circa $80 \%$ ), followed by nitrification (circa $20 \%$ ) (fig. 8). The decrease in the ammonium inventory results from nitrification and subsequent denitrification, and depresses export production as can be seen in the weakening of the vertical phosphate gradient (fig. 8). After depletion of the initial ammonium inventory, reoxidation of organic matter becomes a more significant sink of oxygen and the external sink becomes relatively weaker over time. After cessation of the external oxygen sink at $150 \mathrm{Myr}$ the ocean remains severely nitrogen limited and resembles the low nitrogen, low oxygen steady state for the following $250 \mathrm{Myr}$. The dominant oxygen sink at this time is organic matter remineralization. Only after the shelf width approaches $400 \mathrm{~km}$ after $490 \mathrm{Myr}$ does net oxygen production increase sufficiently to allow an accumulation of nitrate (that is, nitrification exceeds denitrification as shown in fig. 4). The resulting production of atmospheric oxygen (fig. 8) is 

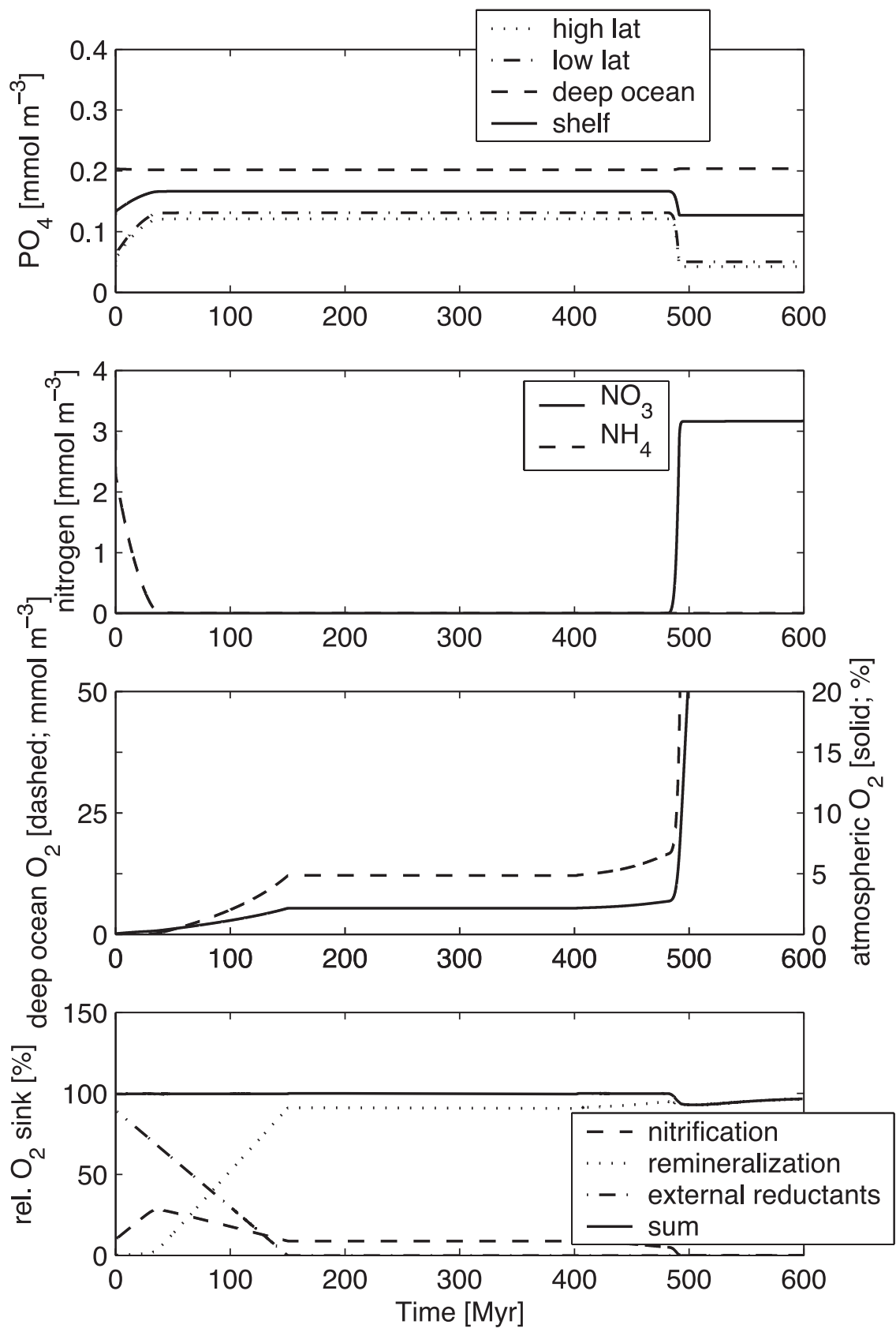

Fig. 8. Model results for an external oxygen sink during the first $150 \mathrm{Myr}$ of the simulation and temporally increasing shelf width. Shelf width starts at $100 \mathrm{~km}$ and reaches $400 \mathrm{~km}$ after 500 Myr. Phosphate concentration, deep ocean nitrogen and ammonium, deep ocean oxygen and atmospheric oxygen ratio, and relative strength of oxygen sink processes are shown (top panel top bottom). The relative oxygen sinks were calculated by dividing the oxygen consumption flux of each process by the oxygen production flux due to photosynthesis. Net oxygen production only occurs when the sum of all relative sinks (indicated by the solid line) is smaller than one. 
unrealistically optimistic because oxygen sinks, like the oxidation of organic matter at subductive margins and continental oxidative weathering are not included (after 150 Myr the only oxygen sinks present in the model are the oxidation of sinking organic matter and nitrification of ammonium).

This simulation produces three biogeochemical stages over time: (i) a reduced deep ocean, (ii) a low nitrogen ocean, and (iii) a fully oxidized ocean. In the initial stage, when the surface ocean and atmospheric oxygen levels are low and the deep ocean remains anoxic, ammonium is a stable nutrient and abundant. In the second, low nitrogen stage, when oxygen is low but present in the deep ocean, neither ammonium nor nitrate are stable and the ocean is severely nitrogen limited. In the third, fully oxidized stage, nitrate is stable and abundant. We infer that in the process of oxidizing the Proterozoic ocean the system had to go through a phase where neither form of fixed nitrogen was stable, which must have resulted in severe limitation of phytoplankton production and, hence, represented a negative feedback on oxygen production.

\section{CONCLUSIONS}

The results of our simple box model clearly suggest that the rise of oxygen in Earth's atmosphere could have been significantly delayed due to oxygen feedbacks on the nitrogen cycle. When free oxygen became available, it permitted ammonium to be converted to nitrate, which can be rapidly reduced to $\mathrm{N}_{2}$ gas, decreasing the pool of bioavailable nitrogen in the ocean and thus providing a negative feedback on oxygen production. The loss of fixed nitrogen would have resulted in a low nitrogen state of the ocean at the anoxic/oxic transition, and represented a barrier to oxidizing the planet. Only after the ocean-atmosphere system moved past the denitrification feedback was a new stable state with abundant nitrate reached. It has been suggested previously that low phosphate availability during the Archean and early Proterozoic eras contributed to low atmospheric oxygen levels by depressing the photosynthetic production of organic matter and hence organic matter burial and net oxygen production (Bjerrum and Canfield, 2002). Bjerrum and Canfield (2002) estimated that phosphate removal due to adsorption onto iron oxide deposits reduced phosphate availability by 90 to 75 percent compared to its present day value. Our results suggest that nitrogen removal due to denitrification at the oxic/anoxic transition was a parallel process that depleted fixed nitrogen in the ocean.

The history of organic matter burial can be inferred from sedimentary records of the $\delta^{13} \mathrm{C}$ signal of carbonates (for example, Des Marais and others, 1992). Relatively large variations in $\delta^{13} \mathrm{C}$ of carbonates have been reported at the beginning (before $1850 \mathrm{Ma}$ ) and the end (after $1250 \mathrm{Ma}$ ) of the Proterozoic eon, both times of increased oxidation of the biosphere, but variations in the intervening interval are relatively small (Knoll and others, 1986; Kaufman and Knoll, 1995; Buick and others, 1995; Karhu and Holland, 1996; Braiser and Lindsay, 1998; Bartley and others, 2001). The mid-Proterozoic stasis has been suggested to indicate low overall productivity due to a change in nutrient regime (Anbar and Knoll, 2002). We propose that such a change in nutrient regime could have resulted from the negative feedback of the nitrogen cycle on the early evolution of oxygen and our model results are consistent with this hypothesis. Major continental rifting and orogenesis appear to have occurred after $1250 \mathrm{Ma}$, ending the stasis in carbonate $\delta^{13} \mathrm{C}$ (Braiser and Lindsay, 1998). An increase in sea level and in phosphate inputs could have resulted from the tectonic activity. Our model system is sensitive to such changes, in particular, increases in shallow shelf area and phosphate inventory can lead to net oxygen production consistent with the apparent increase of Earth's oxidation state at that time (Des Marais and others, 1992).

Evidence for Proterozoic changes in the nitrogen cycle, which we suggest would have had a major influence on the oxidation of the earth, should be recorded in the 
nitrogen isotopic composition of sedimentary organic matter because denitrification results in an isotopic fractionation of nitrogen between the atmosphere and ocean. While there is no marked fractionation during $\mathrm{N}_{2}$ fixation, denitrification preferentially returns ${ }^{14} \mathrm{~N}$ to the atmosphere thus enriching the oceanic nitrogen inventory in ${ }^{15} \mathrm{~N}$, which is recorded by marine organisms. Unfortunately, ${ }^{15} \mathrm{~N}$ records from the Archean and early Proterozoic are sparse. Available measurements of nitrogen isotopic composition from Archean and Proterozoic sedimentary rocks show a shift of the average $\delta^{15} \mathrm{~N}$ from negative values in the early Archean $(3500-3400 \mathrm{Myr})$ to positive values in the early Proterozoic $(2100-1600 \mathrm{Myr})$ but also a large range of values from -7 to 30 percent (Papineau and others, 2005, and references therein). The shift to more positive values has been interpreted as evidence that denitrification began to control the biospheric nitrogen isotope distribution when the oxidation state of the ocean increased at about 2500 Myr ago (Beaumont and Robert, 1999). In contrast, Jia and Kerrich (2004) suggested the positive $\delta^{15} \mathrm{~N}$ values to be the result of a secondary Archean atmosphere derived from CI-chondrite-like material and comets with $\delta^{15} \mathrm{~N}$ of 30 to 42 permil. Filling the time gap between upper Archean and the Paleoproterozoic data that are currently available would be of great value, allowing a more critical evaluation of the role of the nitrogen cycle in the rise of oxygen on Earth.

\section{ACKNOWLEDGMENTS}

Our research is supported by grants from the National Science Foundation and NASA. We wish to thank Jim Kasting, two anonymous reviewers and Larry Anderson for thoughtful comments on an earlier version of the manuscript. We also thank Ilana Berman-Frank, Christian Bjerrum, Donald Canfield and Jim Miller for discussions.

\section{REFERENCES}

Anbar, A. D., and Knoll, A. H., 2002, Proterozoic Ocean Chemistry and Evolution: A Bioinorganic Bridge?: Science, v. 297, p. 1137-1142.

Arnold, G. L., Anbar, A. D., Barling, J., and Lyons, T. W., 2004, Molybdenum Isotope Evidence for Widespread Anoxia in Mid-Proterozoic Oceans: Science, v. 304, p. 87-90.

Bartley, J. K., Semikhatov, M. A., Kaufman, A. J., Knoll, A. H., Pope, M. C., and Jacobsen, S. B., 2001, Global events across the Mesoproterozoic-Neoproterozoic boundary: $\mathrm{C}$ and $\mathrm{Sr}$ isotopic evidence from Siberia: Precambrian Research, v. 111, p. 165-202.

Beaumont, V., and Robert, F., 1999, Nitrogen isotope ratios of kerogens in Precambrian cherts: a record of the evolution of atmosphere chemistry?: Precambrian Research, v. 96, p. 63-82.

Bekker, A., Holland, H. D., Wang, P. L., Rumble, D., Stein, H. J., Hannah, J. L., Coetzee, L. L., and Beukes, N. J., 2004, Dating the rise of atmospheric oxygen: Nature, v. 427, p. 117-120.

Bjerrum, C. J., and Canfield, D. E., 2002, Ocean productivity before about $1.9 \mathrm{Gyr}$ ago limited by phosphorus adsorption onto iron oxides: Nature, v. 417, p. 159-162.

Braiser, M. D., and Lindsay, J. F., 1998, A billion years of environmental stability and the emergence of eukaryotes; new data from northern Australia: Geology, v. 26, p. 555-558.

Brocks, J. J., Logan, G. A., Buick, R., and Summons, R. E., 1999, Archean Molecular Fossils and the Early Rise of Eukaryotes: Science, v. 285, p. 1033-1036.

Buick, R., 1992, The Antiquity of Oxygenic Photosynthesis: Evidence from Stromatolites in SulphateDeficient Archaean Lakes: Science, v. 255, p. 74-77.

Buick, R., Des Marais, D. J., and Knoll, A. H., 1995, Stable isotopic compositions of carbonates from the Mesoproterozoic Bangemall Group, northwestern Australia: Chemical Geology, v. 123, p. 153-171.

Canfield, D. E., 1998, A new model for Proterozoic ocean chemistry: Nature, v. 396, p. 450-453.

Canfield, D. E., and Teske, A., 1996, Late Proterozoic rise in atmospheric oxygen concentration inferred from phylogenetic and sulphur-isotope studies: Nature, v. 382, p. 127-132.

Canfield, D. E., Habicht, K. S., and Thamdrup, B., 2000, The Archean Sulfur Cycle and the Early History of Atmospheric Oxygen: Science, v. 288, p. 658-661.

Catling, D. C., Zahnle, K. J., and McKay, C. P., 2001, Biogenic Methane, Hydrogen Escape, and the Irreversible Oxidation of Early Earth: Science, v. 293, p. 839-843.

Chandler, F. W., 1980, Proterozoic redbed sequences of Canada: Canada Geological Survey, Geological Survey Bulletin, v. 311, 53 p.

Christensen, J. P., 1994, Carbon export from continental shelves, denitrification and atmospheric carbon dioxide: Continental Shelf Research, v. 14, p. 547-576.

Des Marais, D. J., Strauss, H., Summons, R. E., and Hayes, J. M., 1992, Carbon isotope evidence for the stepwise oxidation of the Proterozoic environment: Nature, v. 359, p. 605-609. 
Falkowski, P. G., 1997, Evolution of the nitrogen cycle and its influence on the biological sequestration of $\mathrm{CO}_{2}$ in the ocean: Nature, v. 387, p. 272-275.

Farquhar, J., Bao, H., and Thiemens, M., 2000, Atmospheric Influence of Earth's Earliest Sulfur Cycle: Science, v. 289 , p. $756-758$

Fennel, K., Spitz, Y. H., Letelier, R. M., Abbott, M. R., and Karl, D. M., 2002, A deterministic model for N fixation at stn. ALOHA in the subtropical North Pacific Ocean: Deep-Sea Research II, v. 49, p. 149-174.

Holland, H. D., 1984, The Chemical Evolution of the Atmosphere and Oceans: Princeton, Princeton University Press, $582 \mathrm{p}$.

— 1994, Early Proterozoic atmosphere change, in Bengston, S., editor. Early Life on Earth, Nobel Symposium no. 84: New York, Columbia University Press, p. 237-244.

2002, Volcanic gases, black smokers, and the Great Oxidation Event: Geochimica et Cosmochimica Acta, v. 66, p. 3811-3826.

Jia, Y., and Kerrich, R., 2004, Nitrogen 15-enriched Precambrian kerogen and hydrothermal systems: Geochemistry, Geophysics, Geosystems, v. 5, Q07005, doi:10.1029/2004GC000716.

Karhu, J. A., and Holland, H. D., 1996, Carbon isotopes and the rise of atmospheric oxygen: Geology, v. 24, p. $867-870$.

Karl, D., Michaels, A., Bergman, B., Capone, D., Carpenter, E., Letelier, R., Lipschultz, F., Pearl, H., Sigman, D., and Stal, L., 2002, Dinitrogen fixation in the world's oceans: Biogeochemistry, v. 57/58, p. 47-98.

Kasting, J. F., Holland, H. D., and Kump, L. R., 1992, Atmospheric evolution: the rise of oxygen, in Schopf, J. W., and Klein, C., editors, The Proterozoic Biosphere: New York, Cambridge University Press, p. 159-163.

Kaufman, A. J., and Knoll, A. H., 1995, Neoproterozoic variations in the C-isotopic composition of seawater: stratigraphic and biogeochemical implications: Precambrian Research, v. 73, p. 27-49.

Knoll, A. H., 1996, Archaen and Proterozoic paleontology, in Jansonius, J., and MacGregor, D. C., editors, Palynology: Principles and Applications: Dallas, Texas, American Association of Stratigraphic Palynologists Foundation, v. 1, p. 51-80.

Knoll, A. H., Hayes, J. M., Kaufman, A. J., Swett, K., and Lambert, I. B., 1986, Secular variation in carbon isotope ratios from Upper Proterozoic successions of Svalbard and East Greenland: Nature, v. 321, p. $832-838$

Lenton, T. M., and Watson, A. J., 2000a, Redfield revisited 1. Regulation of nitrate, phosphate, and oxygen in the ocean: Global Biogeochemical Cycles, v. 14, p. 225-248.

2000b, Redfield revisited 2. What regulates the oxygen content of the atmosphere?: Global Biogeochemical Cycles, v. 14, p. 249-268.

Martin, J. H., Knauer, G. A., Karl, D. M., and Broenkow, W. W., 1987, VERTEX: carbon cycling in the northeast Pacific: Deep-Sea Research, v. 34, p. 267-285.

Ohki, K., Rueter, J. G., and Fujita, Y., 1986, Cultures of the cyanophytes Trichodesmium erythraeum and T. thiebautii in a synthetic medium: Marine Biology, v. 91, p. 9-13.

Ohki, K., Zehr, J. P., Falkowski, P. G., and Fujita, F., 1991, Regulation of nitrogen fixation by different nitrogen sources in the marine non-heterocystous cyanobacterium Trichodesmium sp. NIBB 1067: Archives of Microbiology, v. 156, p. 335-337.

Papineau, D., Mojzsis, S. J., Kahru, J. A., and Marty, B., 2005, Nitrogen isotopic composition of ammoniated phyllosilicates: case studies from Precambrian metamorphosed sedimentary rocks: Chemical Geology, v. 216 , p. $37-58$.

Press, W. H., Teukolsky, S. A., Vetterling, W. T., and Flannery, B. P., 2002, Numerical Recipes in C ++ , Second Edition: New York, Cambridge University Press, 1002 p.

Suess, E., 1980, Particulate organic carbon flux in the oceans-surface productivity and oxygen utilization: Nature, v. 288, p. 260-263.

Summons, R. E., Jahnke, L. L., Hope, J. M., and Logan, G. A., 1999, 2-Methylhopanoids as biomarkers for cyanobacterial oxygenic photosynthesis: Nature, v. 400, p. $554-557$.

Toggweiler, J. R., and Sarmiento, J. L., 1985, Glacial to interglacial changes in atmospheric carbon dioxide: The critical role of ocean surface water at high latitudes, in Sundquist, E., and Broecker, W. S., editors, The Carbon Cycle and Atmospheric $\mathrm{CO}_{2}$ : Natural variations Archean to Present: American Geophysical Union, Geophysical Monograph, n. 52, p. 163-184.

Walker, J. C. G., Klein, C., Schidlowski, M., Schopf, J. W., Stevenson, D. J., and Walter, M. R., 1983, Environmental evolution of the Archean-Early Proterozoic earth, in Schopf, J. W., editor, Earth's earliest biosphere: Its origin and evolution: Princeton, Princeton University Press, p. 260-290. 